\title{
Reconstruction and Practice of Teaching System of Environmental Engineering Specialty under the Background of Engineering Education Accreditation
}

\author{
Shuaijie Wang, Ying Liu, Yandi Rao, Yao Guan, and Siru Chen
}

\begin{abstract}
The accreditation of engineering education is the only way to push forward the reformation of higher engineering education and build a new mode of higher engineering education which is in line with international standards. In this paper, the teaching system of environmental engineering specialty which meets the requirements of engineering education accreditation standard was rebuilt based on the OBE mode. The teaching links such as professional talents training objectives, the rationality of graduation requirements, and the teaching of courses were reviewed and improved. The results provide a scientific reference for further promoting the reformation of Chinese environmental engineering education, improving the quality of engineering education and promoting international recognition of the education of Environmental Engineering.
\end{abstract}

Index Terms - Course teaching reformation, engineering education accreditation, graduation ability requirement, OBE mode, training goal.

\section{INTRODUCTION}

At present, the Washington agreement has the highest popularity among the three international agreements on the mutual recognition of engineering education, which has an important and extensive influence. On June 19, 2013, at the International Engineering Alliance Conference held in Seoul, Korea, China formally joined the "Washington Agreement" as a preparatory member, which meant that Chinese engineering education accreditation had been generally recognized by the contracting countries. Professional accreditation and evaluation is an important part of the "fivein- one" teaching quality evaluation system of the "Opinions on the Evaluation of Undergraduate Teaching in higher education institutions" published by the Chinese Ministry of Education. In 1992, China carried out the pilot work on Engineering Education Accreditation of 5 majors in civil engineering.In March 2006, Ministry of Education and Association for Science and Technology of China began to start a comprehensive engineering education accreditation. In 2007, the certified majors expanded to nine, including

Manuscript received September 24, 2017; revised December 15, 2017 This work was supported in part by the Hebei provincial higher education teaching reform research and practice project under Grant 2016GJJG042.

S. J. Wang, Y. D. Rao, Y. Guan, and S. R. Chen are with School of Environment and Chemical Engineering, Yanshan University, Qinhuangdao 066004, People's Republic of China (e-mail: wangshuaijie@ysu.edu.cn, ryd1989@ysu.edu.cn,947927817@ qq.com,810431221@qq.com).

Y. Liu is with Consulting Department, China Electronics Engineering Design Institute, Beijing 100840, People's Republic of China (e-mail:fvpazc@sina.com). environmental engineering.

With the increasingly severe environmental situation and the great concern of the country on environmental quality, the education of environmental engineering has developed rapidly in China [1]-[3]. However, measured by engineering education accreditation standards, there are serious flaws in the Chinese teaching system of Environmental Engineering Specialty [4]-[6]. For example, the training objectives of environmental engineering specialty are not accurate enough; there is a serious tendency of emphasizing science and neglecting technology in the teaching system; the practical courses are seriously insufficient; students lack the understanding of the important function of engineering design in engineering and engineering education; innovative education and the cultivation of innovation consciousness has not received enough attention; not enough attention has been paid to the cultural construction of the environment discipline, which is unfavorable to train students' comprehensive theoretical accomplishment and broaden their horizons. In order to integrate with the engineering education certification, promote the benign development of environmental engineering specialty and improve the employment competitiveness of students, it is imperative to rebuild the teaching system of environmental engineering which meets the requirements of engineering education accreditation standards.

Outcomes-Based Education (OBE) mode is widely used in engineering education accreditation standards, with the output-oriented principle, with all students as the center, and with the continuous improvement of quality as basic purpose [7]-[9]. In this paper, through constructing teaching system of environmental engineering specialty in accordance with engineering education accreditation standards, the teaching links such as professional talents training objectives, the rationality of graduation requirements, course teaching are reviewed and improved based on the idea of Outcomes-Based Education, to meet internationally recognized requirements for environmental engineering graduates and requirements for professional competence of environmental engineers.

\section{REDEFINING PROFESSIONAL TRAINING OBJECTIVES AND GRADUATION ABILITY REQUIREMENTS}

Professional certification standard specified that the professions should have the training objectives which were open, consistent with school positioning, adapting to the needs of social and economic development. In order to make 
the professional training objectives and graduation ability requirements fit social needs more, and meet the requirements of international engineering community for environmental engineering graduates, a questionnaire survey was carried out on 25 environmental enterprises, universities and research institutes outside the university. The questionnaire has set up a series of questions aiming at the basic qualities and abilities that should be possessed by graduates, including the humanities sciences and social sciences accomplishment, social responsibility and the engineering professional ethics, professional elementary theory, innovation attitude and awareness, organization and management ability, expression ability and interpersonal communication ability, life-long learning ability, international vision and the ability to cross-cultural communication, the ability of competition and cooperation. Survey results show that more than $70 \%$ of the units believe that students should have good humanistic and social science accomplishment, social responsibility and engineering professional ethics. Nearly $100 \%$ of the units believe that students should have relevant professional knowledge, certain research and development capabilities and can study continuously to expand their knowledge and ability. Within five years after graduation, students should be able to work independently in the fields of engineering design, engineering commissioning, environmental planning and management and so on. More than $80 \%$ of the units believe that, in addition to the relevant knowledge, students' teamwork ability, sense of responsibility and professional ethics should be enhanced.

According to the results of questionnaire survey, the professional training objectives of specialty training are determined as follows:

To train high-level engineering talents with the concept of sustainable development, with the knowledge of environmental monitoring and assessment, water, gas, sound, solid waste and other pollution prevention, environmental planning and management, drainage engineering and other aspects, with the ability of design and operation management of pollution control engineering, with the ability to formulate environmental plans and conduct environmental management, with the ability of research and development of new theories, new technologies and new equipments in the filed of environmental engineering, with a strong sense of innovation and team spirit, who is able to work independently in the environmental protection departments, design units, planning departments, and independently engaged in engineering design, engineering commissioning, environmental planning and management within five years after graduation.

Graduation ability requirements is determined as follows:

1) Engineering knowledge; Graduates should be able to use mathematics, chemistry, physics, biology and other basic knowledge of natural science, basic knowledge of engineering and professional knowledge to analyse and solve the complex engineering problems in the field of environmental protection.

2) Problem analysis; Graduates should be able to apply the basic principles of mathematics, natural science and environmental engineering to identify, express, and analyse complex engineering problems in the field of environmental protection and obtain effective conclusions.

3) Design/development solutions; Graduates should be able to apply relevant theories, principles and methods in the field of environmental engineering to design and develop reasonable pollution control process and environmental protection equipment, and form a reasonable plan. And should be able to design a system, unit (component) or process that meets a particular requirement, taking into account society, health, safety, law, culture, environment, and other factors.

4) Research; Graduates should be able to use scientific methods to study complex engineering problems in the field of environmental protection, including designing experiments, analysis and interpretation of data, and gaining reasonable and effective conclusions through the information synthesis.

5) Use of modern tools; Graduates should be able to develop, select and use appropriate environmental information technology, detection means and analysis instruments to solve complex engineering problems in the field of environmental protection.

6) Engineering and society; Graduates should be able to analyse and evaluate reasonably the impact of professional engineering practices and complex engineering problem solutions on society, health, safety, law and culture based on environmental engineering basic knowledge, and able to understand their responsibilities.

7) Environment and sustainable development; Graduates should be able to understand and evaluate the impact of professional engineering practices on environmental and social sustainability.

8) Professional norms; Graduates should have the humanistic and social sciences accomplishment, sense of social responsibility, and be able to understand and abide by engineering professional ethics and norms in engineering practice.

9) Individuals and teams; Graduates should be able to take on roles of individuals, team members, and leaders in a multidisciplinary team.

10)Communication; Graduates should be able to communicate effectively with industry colleagues and the public on complex engineering issues, including writing reports, designing presentations, statements, clear expression, or responsing commands. And should have a certain international vision, so as to communicate in a cross-cultural context.

11) Project management; Graduates should be able to use the principles of project management and the method of economic decision making in the fields of design, operation and management of environmental protection projects.

12)Lifelong learning; Graduates should have the consciousness of independent learning and lifelong learning, and have the ability to learn and adapt to development. Graduates should be able to understand the latest theories, technologies and international trends in the field of environmental engineering. 


\section{REFORMATION OF COURSE TEACHING}

Taking the core course of environmental engineering teaching system-- Microbiology of water treatment as a representative, the teaching reformation was carried out from the aspects of teaching contents, teaching links and teaching methods based on the OBE mode.

\section{A. Reformation of Teaching Contents and Teaching Links}

According to the idea of OBE education, the teaching content should reflect the support to teaching goal, students' engineering practice training should be strengthened in the teaching process and teaching content, the cultivation of students' engineering consciousness and innovative consciousness should be focused on. Therefore, in the course teaching reformation, based on the existing teaching links, we added a practical link -- course research project "Biological treatment of domestic sewage in Yanshan University". Based on microbiology experiment of water treatment, the content of the original experiment was reintegrated with the contents of the new project, and a professional, systematic, comprehensive and practical project system was constructed.

Microorganisms are small in size, diverse in shape and have great potential for the treatment of organic pollutants. Sewage treatment plants usually use microbiological methods to treat domestic sewage and industrial wastewater. In the biological process of water treatment, it is usually necessary to mirror the microorganisms in the sludge, observe the microbial species in the sludge, and determine the number of microorganisms in the sewage, in order to judge the degree of sewage treatment and take corresponding measures to guarantee the normal operation of sewage treatment. Therefore, the specific contents of the project are as follows:

1) Students take the sewage from school, and take the activated sludge from sewage treatment plant as the strain to aerate and cultivate the activated sludge. Through the observation of microorganisms in activated sludge under the microscope, the students analyse the composition of activated sludge, make the morphology and movement state of various microorganisms into small video, and establish the microbial map of water treatment to facilitate further research and learning.

2) Students isolate bacteria from activated sludge and culture the bacteria. The bacteria in the activated sludge are separated by the plate streak method. The bacteria are cultured and counted, and the bacterial growth curve is drawn.

3) Students treat school sewage with cultured activated sludge, measure treatment effect, analyse the problems arising in the sewage treatment process, and put forward effective measures for improvement.

4) Students analyse the active components in sludge, detect the enzymes contained in components, and study the important role of enzymes in degradation of environmental pollutants and the mechanism of activated sludge treatment methods.

5) Students write project report and make a report. The project implementation procedures are as follows:

1) Making project plan; Students are encouraged to search relevant reference materials in the electronic databases, and understand the content of the subject through data retrieval, reading, refining key points ;

2) Implement of project plan ;

3) Summarizing project achievement, writing project reports and conducting project reports.

Through the design and implementation of course research projects, the knowledge points involved in each stage of theoretical teaching and their application in Engineering will be studied and discussed deeply. Taking theoretical analysis of specific problems and the method of solving the problem as the research content, students are guided to think positively and learn actively. Students' ability to analyze, understand and solve theoretical and practical problems will be improved. Students will master the method of using scientific and technical language to discuss relevant problems, and be able to communicate effectively through oral and written communication. At the same time, students' team work and communication skills within the team will be trained.

\section{B. Reformation of Teaching Methods}

In the course of microbiology of water treatment, the original teaching method is centered on the teaching materials and the teaching method, the teacher is responsible for the learning process and the teaching method emphasizes the objectives that the teacher wishes to achieve. Students are passive learners, who take exams as the driving force to study. The experimental teaching of the course is based on the verification experiment, and the students' ability to analyze and solve problems can not be fully trained. Aiming at the drawbacks of the original teaching organization style, the teaching link based on ability training was designed.The teaching method was reformed from the aspects of class teaching, course research project and experiment respectively.

1) The teaching method of class teaching is mainly based on the lecture method, and interpretation teaching, demonstration teaching, question and answer teaching are used comprehensively. The teacher explains the basic knowledge of microbiology, the basic principles of biological water treatment methods. In light of the practical problems of the basic principles in specific projects, we should guide students to think actively, teach them by demonstration, ask questions and answer teaching methods to strengthen their practical consciousness.

2) The course project adopts task driven teaching method, supplemented by autonomous learning and discussion. The students are divided into several groups, and a task book is sent to each group. The teams look up information, design experiment plans, and write project reports for tasks. Problems arising during the project are discussed and solved within the group.

3) The main teaching methods of the experiment include demonstration, task driving and self-regulated learning. Students actively learn experimental principles and related operation methods according to the designed experimental program. The teacher demonstrates the difficulty in the project or the experimental operation 
which the students have not practiced, and guides the students to operate.

\section{Reformation of Course Assessment Method}

Accordingly, the course assessment method was reformed. The form of assessment was enriched, which pay attention to the evaluation of knowledge application ability, practical ability, problem solving ability and innovation ability. The course performance consists of 3 parts, namely, the final examination, the experiment and the project results. Specific requirements and performance evaluation methods are as follows:

1) Final examination. The final examination result accounts for $60 \%$ of the total course performance, which is evaluated according to the correct degree of the examination paper.

2) Experiment. Students are required to prepare carefully, participate in the whole process and submit lab reports on time. If the experiment report is not submitted on time or plagiarisms, the result of the experiment is zero. The experimental result accounts for $10 \%$ of the total course performance, which is evaluated from two aspects:

The writing of the experiment report $(50 \%$ of the experimental results);

Experimental operating (50\% of the experimental results).

3) Project. Students are required to participate in the whole process, make PPT, report and plead, and write project research reports. The project result accounts for $30 \%$ of the total course performance, which consists of two parts: group performance and performance within group.

The group performance accounts for $80 \%$ of the project result, which is evaluated in three ways:

The rationality and advancement of the project design(20\% of group performance);

The presentation of PPT ( $40 \%$ of group performance);

The logicality and accuracy of project research report $(40 \%$ of group performance).

The performance within group accounts for $20 \%$ of the project result, which is determined by each team member's contribution within the group. However, the difference between the highest score and the minimum score between members can't be less than $15 \%$. If the project report is not submitted on time or plagiarisms, the project result is zero.

The course assessment process of water treatment microbiology in 2016-2017 academic year was taken as an example to illustrate the course assessment method. The scores of were shown as follows.

TABLE I: SCORES OF THE COURSE OF MICROBIOLOGY OF WATER TREATMENT

\begin{tabular}{|c|c|c|c|c|c|}
\hline Number & Name & $\begin{array}{l}\text { Experimental } \\
\text { Score }\end{array}$ & $\begin{array}{l}\text { Examination } \\
\text { Score }\end{array}$ & $\begin{array}{l}\text { Project } \\
\text { Score }\end{array}$ & $\begin{array}{l}\text { Total } \\
\text { Score }\end{array}$ \\
\hline 1 & Song Xx & 9 & 45.5 & $\begin{array}{l:}29 \\
\end{array}$ & 83.5 \\
\hline 2 & Fan Xx & 10 & 45.5 & 29 & 84.5 \\
\hline 3 & Ma Xx & 10 & 30.5 & 29 & 69.5 \\
\hline 4 & Chen $\mathrm{xx}$ & 10 & 58 & 29 & 97 \\
\hline 5 & Li xx & 9 & 57 & 30 & 96 \\
\hline 6 & Wang $\mathrm{xx}$ & 10 & \begin{tabular}{|l|l}
44 \\
\end{tabular} & \begin{tabular}{|l|l}
29 \\
\end{tabular} & \begin{tabular}{|l|l}
83 \\
8
\end{tabular} \\
\hline
\end{tabular}

\begin{tabular}{|c|c|c|c|c|c|}
\hline 7 & Deng xx & 9 & 44 & 29 & 82 \\
\hline 8 & $\begin{array}{l}\text { Liang } \mathrm{xx} \\
\end{array}$ & 10 & 29.5 & 27 & 66.5 \\
\hline 9 & Cheng $\mathrm{xx}$ & 10 & 49 & 27 & 86 \\
\hline 10 & Wang $\mathrm{xx}$ & 9 & 32.5 & 27 & 68.5 \\
\hline 11 & Jing $\mathrm{xx}$ & 10 & 28 & 27 & 65 \\
\hline 12 & Zhang xx & 9 & 50.5 & 27 & 86.5 \\
\hline 13 & Zou Xx & 8 & 51.5 & 28 & 87.5 \\
\hline 14 & $\begin{array}{l}\text { Zhang } \mathrm{xx} \\
\end{array}$ & 9 & 45 & 27 & 81 \\
\hline 15 & Chen xx & 9 & 53 & 27 & 89 \\
\hline 16 & Ren $x x$ & 9 & 29 & 27 & 65 \\
\hline 17 & Lixx & 9 & 45 & 27 & 81 \\
\hline 18 & $\operatorname{Lixx}$ & 10 & 55.5 & 27 & 92.5 \\
\hline 19 & Gong xx & 10 & 33.5 & 27 & 70.5 \\
\hline 20 & Liu xx & 9 & 37 & 28 & 74 \\
\hline 21 & Zeng $\mathrm{xx}$ & 9 & 51 & 27 & 87 \\
\hline 22 & Zhao xx & 10 & 45 & 27 & 82 \\
\hline 23 & Yang Xx & 10 & 25.5 & 27 & 62.5 \\
\hline 24 & $\operatorname{Lin} x x$ & 9 & 55 & 27 & 91 \\
\hline 25 & Zhao xx & 10 & 36.5 & 27 & 73.5 \\
\hline 26 & Sui xx & 8 & 35.5 & 27 & 70.5 \\
\hline 27 & Liu xx & 10 & 53.5 & 28 & 91.5 \\
\hline 28 & Zhang xx & 10 & 34 & 27 & 71 \\
\hline 29 & $\operatorname{Lixx}$ & 9 & 51.5 & 27 & 87.5 \\
\hline 30 & Cui xx & 10 & 41.5 & 28 & 79.5 \\
\hline 31 & Zhang xx & 9 & 51 & 27 & 87 \\
\hline 32 & Wang $\mathrm{xx}$ & 9 & 43.5 & 27 & 79.5 \\
\hline 33 & Tong xx & 9 & 30.5 & 27 & 66.5 \\
\hline 34 & Tang xx & 10 & 27 & 27 & 64 \\
\hline 35 & $\mathrm{Xu} \mathrm{xx}$ & 9 & 43 & 27 & 79 \\
\hline
\end{tabular}

\section{CONCLUSION}

Under the background of engineering education accreditation, the teaching reform has taken the detailed social investigation results as the core to formulate the corresponding specialized training goal and the graduation ability request. Taking the course of Microbiology of water treatment as a representative, the course teaching reform was carried out. Through the teaching reform of the course of Microbiology of water treatment, nearly $100 \%$ of the students thought that the introduction of the practice and reform of teaching methods could deepen students' awareness and understanding of the basic principle and basic knowledge of water treatment microbiology, could guide students to think actively, and improve the abilities of students to apply the specialized knowledge comprehensively to analyze and solve the practice problem of the professional and related industries. The course teaching paid more attention to the cultivation of students' engineering practice consciousness, and improved students' 
team cooperation ability and communication ability. The results of the teaching reform provide a scientific reference for further promoting the reformation of Chinese environmental engineering education, improving the quality of engineering education and promoting international recognition of Environmental Engineering Education.

\section{ACKNOWLEDGMENT}

The authors gratefully acknowledge the support from the Hebei provincial higher education teaching reform research and practice project (Grant No. 2016GJJG042).

\section{REFERENCES}

[1] S. H. Lan, Y. T. Wang, and X. W. Wu, "The thinking of "engineering education of excellence program" of environmental engineering specialty practice teaching system reform," Revista Medica Del Imss, vol. 174, no. 6, pp. 17-21, 2014.

[2] Y. Peng and X. H. Wang, "The teaching experience and reform discussion of environmental engineering practice," Vocational Education Research, pp. 116-117, 2010.

[3] J. Gong, L. Wang, X. E. Li, Z. M. Liu, D. J, Ren, and T. Feng, "Discussing on practice reform of environmental engineering specialty," presented at 2nd International Conference on Modern Education and Social Science(MESS), pp. 15-17, 2016.

[4] Y. Jiang and J. Chen, "Analysis of teaching reform of environmental engineering specialty under the accreditation of engineering education specialty," Journal of Zhejiang University of Technology (SOCIAL SCIENCE EDITION), vol. 13, no. 3, pp. 256-260, 2014.

[5] L. Jiang, W. P. Liu, G. B. Liang, and D. C. Li , "Exploration of seminar teaching model in practice of environmental engineering," Journal of Jiangsu Teachers University of Technology, vol. 19, no. 2, pp. 114-117, 2013.
[6] J. Y. Cao, J. Xu, Z. D. Chen, and Y. R. Wang, "Educational reform and practice of applied chemistry under the background of accreditation of engineering education," Guangzhou Chemical Industry, vol. 44, no. 18, pp. 190-192, 2016

[7] O. Akir, T. H. Eng, and S. Malie, "Teaching and learning enhancement through outcome-based education structure and technology e-learning support," Procedia-Social and Behavioral Sciences, vol. 64, pp. 87-92, 2012.

[8] B. Q. Shan and Y. Liu, "Exploration of teaching system of environmental engineering based on OBE model," Education in Shanxi: Higher Education, no. 3, pp. 64-65, 2016.

[9] Y. G. Yang, B. Meng, and W. N. Wang, "Cultivation of technological innovation ability based on OBE model," Higher Engineering Education Research, no. 6, pp. 24-30, 2015.

Wang Shuaijie was born in Hebei Qinhuangdao, 1978. In 2004, she received her Ph. D. degree in environmental science from Nankai University. Her major field of study is environmental pollution control.

Liu Ying was born in Liaoning Huludao, 1976. In 2001, she received her master degree in environmental engineering from Dalian University of Technology. Her major field of study is environmental impact assessment.

Rao Yandi was born Hebei Xingtai, 1989. In 2015, she received her master degree in environmental engineering from Yanshan University. Her major field of study is photocatalytic oxidation technology.

Guan Yao was born in Hebei Tangshan, 1994. In 2016, she received her bachelor degree in environmental engineering from Yanshani University. Her major field of study is environmental microbiology.

Chen Siru was born Shanxi Yulin, 1992. In 2015, he received his Bachelor degree in environmental engineering from Yanshan University. His major field of study is environmental microbiology. 